\title{
Nature of Evil in Macbeth
}

\author{
Md. Saiful Islam, $P h D^{*}$
}

\section{Introduction}

"It is a statement of evil" (Knight 18).

"The Whole play may be writ down as a wrestling of destruction with creation" (Knight 140).

"It contains the decisive orientation of Shakespearean good and evil" (Traversi 86).

The above statements serve to prove that Macbeth is Shakespeare's most profound and mature vision of evil. In this play, Shakespeare presents the overspreading influence of evil over the guilty and ambitious minds which lead them to commit the most treacherous villainy that affect not only the man and the state, but the family and the physical universe as well. But this evil is not the one that finally triumphs, Shakespeare in this play also provides the essential morality and courage which in their progression defeat the evil and restore the natural order of things. This paper endeavors to present the various viewpoints from which this evil can be interpreted. It shows how Shakespeare has depicted the transformation of a good person to a ghastly figure. The effect of evil in Lady Macbeth is also analyzed. The paper also tries to examine whether this evil is purely psychological or has an exterior form.

\section{Macbeth's Transformation from Good to Evil}

In other tragedies of Shakespeare the evil is concentrated in the antagonists who are able to bring about the ruin of better people than themselves by making use of their weakness: pride, credulity and lust. But in Macbeth the evil is transferred from the villains to the hero and the heroine. For instance, Macbeth, the hero of the play

*Associate Professor, Department of Theatre, University of Dhaka 
stands as a perfect embodiment of the disintegration of the individual under the influence of evil. At the start of the play he is a very successful and highly esteemed member of a social group, loaded with honours and enjoying every prospect of further commendation. He has a loving wife and a secure home in his castle at Inverness. He is a man "full of the milk of human kindness" (Shakespeare, Macbeth I.V.17). As the play opens, we learn of his heroic actions in defense of the kingdom. We see him interact with other nobles, and their friendship and esteem are evident, as is Duncan's high regard, which expresses itself in terms of fertile growth, the beauty of natural processes, and spontaneous generosity with promises of more to come. But as he is overpowered by evil and the crime is committed, his human feelings are gradually destroyed until at the end of the play he becomes the unnatural man, cut off from humanity and from God. As his link with humanity weakens, so also does his desire to live, until at last he sinks into total despair which is the surest evidence of his damnation.

\section{Macbeth's Power of Imagination}

It is noteworthy that Macbeth's extraordinary powers of imagination enables him to see all the implications of his evil deed in their most frightening form, before the deed itself is committed. His imagination enables him to grasp the moral implications of the deed he is going to commit, and he can visualize the full horror of the crime. He is fully aware of God's moral system with its "even handed justice" (Shakespeare, Macbeth I.VII.10), which forces the criminal to drink the very cup of poison which he has prepared for another. Macbeth's soliloquy in which he meditates upon Duncan's murder (Act 1, Scene VII. 1-28) shows clearly his feelings of kinship with the moral order before he commits the crime. But Macbeth's exceeding ambition, which represents the evil, is so overwhelming that in the struggle with it his moral consciousness and better feelings get defeated and leave him utterly wretched. His passion for power and his instinct of self-assertion are so vehement that no inward or outward misery could persuade him to relinquish the fruits of crime, or to advance from remorse to repentance. Evidently he commits himself to his course of evil. He deliberately tries to suppress his moral feelings. Just as he gets ready to commit the deed, he makes another soliloquy, and he seeks the suppression of all the moral feelings within himself. In a devilish incantation he calls for darkness and the extinction of nature, appealing to the 
earth itself to look aside while he violates the harmonious order of the world. This violation alienates him from God. Immediately after the murder, Macbeth finds that he cannot utter the word "Amen" (Shakespeare, Macbeth II.II.31). He also finds that he will sleep no more. Sleep is an aspect of divine mercy which offers man an escape from worldly cares. This escape will be denied to Macbeth. Afterwards, Macbeth steadily moves further and further from God and from his fellow human beings. His bond with nature is thus weakened. After the murder of Duncan he commits himself to an unnatural course from which his cannot retreat as he himself says:

I am in blood

Stepped in so far that, should I wade no more,

Returning were as tedious as go over.

(Shakespeare, Macbeth III.IV. 136-38)

\section{Evil in its Most Frightening Form}

At this point, Macbeth is ready to seek the witches in order to get further information about the future and their words lead him to the most horrible brutality, namely the murder of Macduff's family. At the beginning of the play, evil had come to Macbeth unsought, now towards the end he embraces evil willingly and without fear. He is now without any conscience whatsoever. The evil which was latent in him has now come out in its most frightening form. He indulges in tyranny and Scotland suffers:

Each new morn

New widows howl, new orphans cry, new sorrows

Strike heaven on the face.

(Shakespeare, Macbeth IV.III. 4-6)

When evil in one's nature is let loose, it enables one to commit vices which were previously unheard of him. It takes him to the path of doom through vices of the most detestable nature. Malcolm says:

I grant him bloody,

Luxurious, avaricious, false, deceitful,

Sudden, malicious.

(Shakespeare, Macbeth IV.III.58-60) 


\section{Macbeth's Realization}

Ultimately Macbeth realizes his ghastly sin. The evil he has desperately embraced continues to madden or to wither his inmost heart. No experience in the world could bring him to glory in it or make his peace with it, or to forget what he once was. There is nothing left for him but the despair of his speech:

To-morrow, and to-morrow and to-morrow,

Creeps in this petty pace from day to day;

To the last syllable of recorded time;

And all our yesterdays have lighted fools

The way to dusty death. Out, out brief candle!

Life's but a walking shadow; a poor player,

That struts and frets his hour upon the stage.

And then is heard no more: it is a tale

Told by an idiot, full of sound and fury,

Signifying nothing.

(Shakespeare, Macbeth V.V.19-28)

\section{Evil in Lady Macbeth}

The effects of evil are much stronger and obsessive in Lady Macbeth than on Macbeth. "She deliberately chooses evil, her choice being more deliberate than her husband's" (Muir lxvii). She embraces evil more spontaneously than her husband did. Macbeth thinks his "vaulting ambition" (Shakespeare, Macbeth I.VII. 27) stimulates him only, but it is his wife whose reprimands force him to shake off the unwillingness he had to commit murder. When she tells anything, she means it. She literally summons the powers of darkness to overpower her:

Come, you spirits

That tend in mortal thoughts, unsex me here,

And fill me, from the crown to the toe, top-full

Of direst cruelty!

(Shakespeare, Macbeth I.V. 40-43)

Evil can create perverse conceptions. To Lady Macbeth, the meaning of 'Evil' and 'Good' becomes wholly reversed. The 
attainment of the crown by hideous murder seems to her something glorious. She is so firm in her determination of the act that she cannot see it as but glorious. In her soliloquy she says about Macbeth:

Yet do I fear thy nature;

It is too full o' the milk of human kindness

To catch the nearest way; thou wouldst be great;

Art not without ambition, but without

The illness should attend it, what thou wouldst highly,

Thou wouldst thou holily.

(Shakespeare, Macbeth I.V.16-21)

To Lady Macbeth, 'ambition' and 'illness' are terms of praise and 'human kindness' and 'holily' are terms of blame. In the words of Bradley: "Moral distinctions do not in this exaltation exist for her; or rather they are inverted: 'good' means to her the crown and whatever is required to obtain it, evil whatever stands in the way of its attainment" (Bradley 325).

\section{Traces of Goodness in Lady Macbeth}

But it is true that Lady Macbeth is not naturally deprived of consciousness (any more than Satan was). There is in her some trace of human feelings which accounts for her later failure. Her human feelings which lay way inside her, dormant, sometimes come out and make her weak. The labour she wields to subdue her husband's resistance is also to subdue her own resistance to evil. Her weakness is revealed when she says:

Had he not resembled

My father as he slept, I had don't.

(Shakespeare, Macbeth. II.II.12-13)

The excuse for not being able to murder Duncan as he resembled her father is baseless. She could never have done it. She needed wine to strengthen herself even to act as the accomplice.

Evil engulfs everything and everyone, even a strong woman like Lady Macbeth. At the start of the play, Lady Macbeth seems to have a very strong character - almost stronger than Macbeth's - but 
by the end she is reduced to being afraid of the dark. At the beginning she is Macbeth's "dearest partner of greatness" (Shakespeare, Macbeth I.V.11-12), but at the end she is his "fiendlike queen" (Shakespeare, Macbeth. V.IX.35). She has a lust for power, and it is her goading that leads Macbeth to seize the throne of Scotland by murdering Duncan. Lady Macbeth is unable, however, to confront the evil she has unleashed and is driven mad. She is often seen as a symbol of evil like the witches, but at the end she falls victim to evil just like her husband.

\section{The Sleepwalking Scene}

Lady Macbeth's sleepwalking scene is a splendid demonstration of the fatal workings of evil upon a human mind. The sleepwalking shows that the murders weigh heavily upon her mind and allow her no rest, even in her sleep. Her conscience has become a source of torment to her, and she is afraid of darkness. The woman who had said that a little water would clear her and her husband of the deed of murder now says; "What, will these hands never be clean?" (Shakespeare, Macbeth. V.I.42) and "All the perfumes of Arabia will not sweeten this little hand" (Shakespeare, Macbeth. V.I.48-49). She also says in the course of her sleepwalking that nobody could have imagined that the old man, Duncan, had so much blood in him. In short, this scene shows the mental collapse of Lady Macbeth and demonstrates that evil has in it the seeds of self-destruction.

When evil is let loose, it corrupts all creation, not only man and state, but the physical universe as well. Lenox's speech which immediately follows Duncan's murder shows that the physical universe has been thrown out of harmony:

The night has been unruly; where we lay,

Our chimneys were blown down; and, as they say,

Lamentings heard in the air, strange screams of death,

And prophesying with accents terrible.

(Shakespeare, Macbeth II.III.55-58)

The clamoring of the owls at night, the devouring of Duncan's horses by each other, all these suggest something unnatural is going to happen. Even the natural phenomena such as 
the ravens' crook, the sound of the crickets and the coming of the night seem to be foreboding. But this corruption in nature contains within itself the means of restoring harmony. The rebirth of good is implied in the working out of evil. Shakespeare uses the very perversion of nature to herald the downfall of the tyrant and to restore the physical universe to its natural state of perfection. For instance, Birnam Wood moves and Macduff turns out to be a child unborn of a woman.

\section{Evil: External or Internal?}

It should be noted that the evil we are discussing here may be associated with the influences of devils or supernatural powers as well as it may be merely the evil ambitions and deeds of the guilty souls, or both. The critics are divided between themselves in this respect. For instance, some critics have described the Weird Sisters as demons, or devils, in the forms of witches whom Macbeth is powerless to resist. Others argue that, great as is the Weird Sisters' influence on the action, it is so because they are merely symbolic representation of the unconscious or half-conscious guilt in Macbeth himself. Both the views, according to the opinion of A. C. Bradley, are inadequate. He says:

the witches and their prophecies, if they are to be rationalized or taken symbolically, must represent not only the evil slumbering in the hero's soul, but all those obscurer influences of the evil around him in the world which aid his own ambition and the incitements of his wife. Such influences, even if we put aside all belief in evil 'spirits' are as certain, momentous, and terrifying facts as the presence of inchoate evil in the soul itself: and if we exclude all reference to these facts from our idea of the witches, it will be greatly impoverished and will certainly fail to correspond with the imaginative effect. The union of the outward and the inward must be realized here (Bradley 304-5).

The inexplicable powers that work in the outside world affect the inward powers of the soul, making them more powerful and active. The seeds of evil lying dormant in Macbeth's soul leap outside at the words of the witches which prove fatal to him.

In this connection we may consider Lady Macbeth's sleepwalking scene in one way or the other. We may take it literally 
that she was possessed by evil spirits or may see it as symbolizing her consciousness of the guilt and outrage she has discerned on her own soul. The view that Lady Macbeth was literally possessed by demons explains the speaking of the second personality through her mouth confessing sins and sometimes reality, memories as characteristic of demonical somnambulism. Such an interpretation also explains the unnatural darkness and equally unnatural portents on the night of the murder. But in Kenneth Muir's opinion, "the night without stars, the prodigies accompanying the murder, and the sleep-walking of Lady Macbeth can all be explained without bringing in the supernatural at all" (Muir lxx). According to him, there was an ambiguity in Shakespeare's mind regarding this.

\section{Goodness Contrasted to Evil}

Shakespeare in this play created the contrasting good which mitigates evil. This is done partly by means of imagery, symbolism and repetition. The image of the ill-fitting garments is recurrent in the play, and the contrast between light and darkness is part of a general antithesis between good and evil, devils and angels, evil and grace, hell and heaven. The image of the deed too terrible to look at is also significant; and the images of disease in Act IV scene III and in Act V clearly reflect both the evil which is a disease and Macbeth himself who is the disease from which his country suffers. Then there is the concept of honour which occurs again and again in the course of the play. Lady Macbeth prevails upon her husband largely by appealing to his valour. The words and the wounds of the bleeding sergeant are suggestive of honor; so also are the titles bestowed by Malcolm at the end of the play. One of the noblemen pines for "free honours" (Shakespeare, Macbeth III.VI.36), and he speaks as a chorus. Macbeth in the final act laments that he has only "mouth-honor" (Shakespeare, Macbeth V.III.27) instead of true "honor" (Shakespeare, Macbeth IV.III.25). Closely connected with honour are the feudal ideas of duty and service the repetition of which helps to create a picture of an orderly and close knit society, in contrast to the disorder resulting from Macbeth's initial crime. The naturalness of that order, and he unnaturalness of its violation by Macbeth are emphasized by the images of planting and sowing, and the images of sleep and milk contrast with the images of unnatural disorder and the repetition of fear and blood. The contrast 
is most apparent in the lines which express so violently Lady Macbeth's violation of her sex:

I have given suck, and know

How tender 'tis to love the babe that milks me:

I would; while it was smiling in my face,

Have pluck'd my nipple from his boneless gums,

And dash'd the brains out, had I so sworn

(Shakespeare, Macbeth I.VII.54-58)

By such means Shakespeare builds up the order of nature and examines the nature of order, so that the violation of order in the state by the assassination of Duncan is seen to be an unnatural horror, inevitably attended by portents.

\section{The Destruction of Evil}

The destruction of evil and restoration of good is done in the play by the characters like Macduff, Malcolm and King Edward the confessor; their role being the agents of goodness. Although the powers of goodness are conveyed more by symbols and by images than the deeds of individuals comparable in importance to the Macbeths, but these characters do have a strong contribution in the restoration of goodness. Towards the end of the play we find retribution starting to operate to punish the evil-doer, Macbeth. The tyranny of Macbeth arouses Macduff against him, causes Malcom to assert his legitimate claim to the kingship, and makes the saint like King Edward to take arms against Macbeth. In Act IV, Scene II, Shakespeare describes King Edwards's ability to cure a dreadful disease by his touch. This description emphasizes the saintliness of Edward and shows that he is an agent of God, and an instrument of supernatural grace, intended to remove the unnatural evil in the state just as he is able to remove disease from the body of the individual man. Malcolm's victory over Macbeth restores peace, truth and legitimate kingship to Scotland. His last words in the play show the destruction of evil and disorder, and restoration of order, harmony and peace by a young and rightful king of the country: "We will perform in measure, time and love" (Shakespeare, Macbeth V.IX. 39). Accordingly the play ends with the gruesome spectacle of Macbeth's head held aloft on a spear by Macduff. The 
play in its totality shows that there is order and meaning in the universe and that good may return out of evil.

\section{Conclusion}

Thus the play produces in us that feeling of reconciliation which is the ultimate test of tragedy. The moral which is driven home into our hearts is that crime does not pay, that "All the perfumes of Arabia will not sweeten this little hands" (Shakespeare, Macbeth V.I. 48-49), and that, to those who destroy life, life itself becomes merely a tale told by an idiot.

\section{Works Cited}

Bradely, Andrew Cecil. Shakespearean Tragedy. 3rd ed. London: Macmillan, 1992. Print

Knight, George Wilson. The Wheel of Fire; Explorations. New York: Routledge, 1949. Print

Muir, Kenneth. The Arden Shakespeare: Macbeth. London: Methuen and Co. Ltd, 1985.Print

Shakespeare, William. The Arden Shakespeare: Macbeth. India: B. I. Publications Pvt. Ltd. by arrangement with Methuen and Co. Ltd, 1976.Print

Traversi, Derek Antona. An Approach to Shakespeare. Australia: DoubleDay, 1969. Print 